\title{
Blasts 6-19 Percent of Bone Marrow Nucleated Cells
}

National Cancer Institute

\section{Source}

National Cancer Institute. Blasts 6-19 Percent of Bone Marrow Nucleated Cells. NCI

Thesaurus. Code C147056.

A semi-quantitative microscopic finding indicating that between 6 and 19 percent of the nucleated cells in a bone marrow sample are immature mononuclear cells. 